\title{
Research training during medical residency (MIR). Satisfaction questionnaire
}

\author{
A. Ríos Zambudio, F. Sánchez Gascón, L. González Moro and M. Guerrero Fernández \\ Department of General and Digestive Surgery. Comisión de Docencia. University Hospital Virgen de la Arrixaca. El Palmar. \\ Murcia. Spain
}

Ríos Zambudio A, Sánchez Gascón F, González Moro L, Guerrero Fernández $M$. Research training during medical residency (MIR). Satisfaction questionnaire. Rev Esp Enferm Dig 2004; 96: 695-704.

\begin{abstract}
Introduction: it is during Medical Residency Training (MIR) that knowledge, abilities and habits are acquired, which will shape professional activity in the future. It is therefore very likely that residents who do not acquire the necessary habits and knowledge for research activities will eventually not carry out these activities in the future. The aim of this study was to analyze the level of satisfaction of residents with his or her scientific and research training, and to determine any deficiencies with respect to this training.

Materials and methods: the aim of the questionnaire used was to determine the level of satisfaction of residents regarding their scientific and research training during their residency period. Questionnaires were usually distributed via internal mail to all residents (MIR physicians) registered at a third level teaching hospital, with a completion rate of $78 \%(n=178)$.

Results: as far as the evaluation of scientific training is concerned, $68 \%$ of residents were dissatisfied or very dissatisfied. With respect to scientific studies carried out, 49\% of residents had not taken part in any, but the number of studies carried out increases as the residency progresses. On the other hand, $22 \%$ of residents reported not having started their doctoral thesis, 50\% having attended doctorate courses, 24\% having a title for their thesis, and only $4 \%$ having written a thesis. Doctorate courses, thesis topics, and written theses increase with the year of residen$c y$, and a greater activity may be seen in this respect in surgical departments. If we analyze help available to residents for their carrying out scientific activities, 55\% reported that only selected assistant doctors would offer help, and $21 \%$ reported that no doctors would offer help. Dissatisfaction with research training
\end{abstract}

Recibido: 19-01-04.

Aceptado: 17-02-04.

Correspondencia: Antonio Ríos Zambudio. Avda. de la Libertad, 208, Casillas. 30007 Murcia. Fax: 968369 716. e-mail: ARZRIOS@teleline.es increases with the year of residency. With regard to main specialist fields, it can be seen that residents in surgical fields carry out more theses, whereas central fields report less facilities. Finally, if we evaluate the influence that these variables may have on the general satisfaction of residents with his or her residency, these variables are seen to be significant factors of dissatisfaction.

Conclusions: most residents are dissatisfied with their scientific training and have relatively few facilities for developing such skills, which in turn results in a scarce number of scientific studies and doctoral theses.

Key words: Internal residents. Scientific training. Satisfaction. Thesis. Publications.

\section{INTRODUCTION}

It is widely recognized that the training received from the specialist medical training program through the residency system (MIR system) is highly rated and has improved the quality of health care in hospitals (1-3), although there is room for improvement in selected areas (3-10). It is during this postgraduate period of specialization that a doctor's knowledge improves quickly; thus, this period should be made use of as much as possible for the benefit of both doctors and the health system in general (4).

It should be taken into account that it is during this training period that knowledge, skills and habits are acquired in all aspects (clinical, educational, investigational, and ethical), which will mark the doctor's professional future. In this sense, residents who do not acquire the habits and knowledge necessary for carrying out research activities will probably not undertake such activities in the future. Therefore, it is essential that those responsible for teaching residents (MIRs) encourage such activities, in order to train effective residents with effective clinical, scientific, investigative, educational and ethical bases. What is more, it is important to know the current situation of residents with respect to their research training and how they evaluate it.

The objective of this study is to analyze the level of satisfaction of internal residents in our hospital with respect to 
their scientific and research training, as well as to determine deficiencies in their training.

\section{MATERIALS AND METHODS}

The study was carried out in a third-grade hospital accredited for graduate and postgraduate teaching. A questionnaire was designed (15 multiple-choice questions) to evaluate the satisfaction of residents (MIRs) with their scientific and investigative training during the residency period. In the evaluation questions a scale of discrete continuous variables was used (from 0 to 10), which were then grouped into five categories: 0-2 very unsatisfactory; 3-4 dissatisfied; 5-6 normal or indifferent; 7-8 satisfied; and 9-10 very satisfied.

Questionnaires were usually distributed by internal mail during February and March 2002 to all MIRs registered in our hospital at that time. The questionnaire was anonymous and self-directed. It was placed in a sealed envelope and handed in to the secretary of education in our hospital. Of 237 residents, those who were on secondment in other hospitals (service commission) at the time of questionnaire administration were excluded $(n=10)$, the questionnaire being distributed to 227 , with $178(78 \%)$ answering. Three were excluded for being handed in blank, with 175 valid questionnaires $(77 \%)$. There was a slight predominance of women in the survey $(\mathrm{n}=98 ; 56 \%)$, and the average age was $27 \pm 7$ years $(24-45$ years $)$. With respect to the main specialist group, $47 \%(\mathrm{n}=82)$ were medical specialists, $22 \%(\mathrm{n}=38)$ were surgical specialists, and $31 \%(\mathrm{n}=54)$ were in central services; in the remaining case $(0.6 \%)$ the speciality was not specified. When considering year of residency, $22 \%(n=39)$ were residents in the first year, $25 \%(n$ $=44)$ in the second year, $26 \%(n=46)$ in the third, $20 \%(n=$ $34)$ in the fourth, and $5 \%(n=8)$ in the fifth year; in the remaining 4 cases the year of residency was not stated.

Variables analyzed included personal characteristics (age, sex, year of residency, and specialist area), presence of departmental sessions (emergencies, clinical, bibliographical, and morbidity/mortality), an evaluation of the different types of training received by residents (MIRs) (health care, educational, investigative, and ethical), facilities for undertaking scientific activities, facilities for attending courses and congresses, scientific work published, and current doctorate status (thesis already written, thesis topic, doctorate courses, or neither courses nor thesis).

Some descriptive statistics were calculated for each of the variables. In order to detect factors which cause dissatisfaction with residency, a comparison between the global level of satisfaction with residency and the rest of variables was carried out using the chi-squared test, together with an analysis of residues and Fisher's exact test where necessary. A value of $\mathrm{p}$ below 0.05 was considered to be statistically significant.

\section{RESULTS}

With respect to the evaluation of seminars carried out in various departments (emergency, clinical, bibliographical, and morbidity/mortality), clinical seminars are routine in most departments (69\%). However, as can be seen in table I, a high percentage of residents do not have or only occasionally have access to seminars of different types in their departments. Therefore, $85 \%$ claim to never or only occasionally have morbidity/mortality seminars; the same is true of bibliographical seminars in $59 \%$ of cases.

Table I. Different types of seminars available to residents in their departments

\begin{tabular}{lcccc}
\hline & None & Occasionally & Usually & NA \\
\hline Emergency seminars & $76(46 \%)$ & $28(17 \%)$ & $48(29 \%)$ & $15(9 \%)$ \\
Clinical seminars & $15(9 \%)$ & $36(22 \%)$ & $115(69 \%)$ & $1(1 \%)$ \\
Bibliographical seminars & $49(29 \%)$ & $50(30 \%)$ & $66(40 \%)$ & $2(1 \%)$ \\
Morbidity/Mortality seminars & $115(69 \%)$ & $27(16 \%)$ & $11(7 \%)$ & $14(8 \%)$ \\
\hline
\end{tabular}

As far as training is concerned, as can be seen in table II, this varies according to the type of case analyzed. Thus, for clinical care training only $15 \%$ are dissatisfied or very dissatisfied, while this rate rises to $36 \%$ in the educational training evaluation, and to $68 \%$ for investigative training.

Concerning scientific studies, $49 \%$ of residents have not written any article, and the number of published scientific studies increases as the residency progresses, without differences according to specialist group. On the other hand, $22 \%$ of residents report having not started their doctoral thesis, $50 \%$ report having participated in doctorate courses, $24 \%$ have the topic for their thesis, and only $4 \%$ have completed their thesis. Doctorate courses, thesis topic, and the written completion of a thesis increase with the year of residency, and a greater activity was seen in this respect at surgical departments. If we analyze facilities available for residents to carry out scientific activities, $19 \%$ report that there are many, $55 \%$ that only some staff physicians are available, and $21 \%$ that no physicians are available. When considering facilities for attending courses and congresses, 46\% report that there are many, $34 \%$ that there are only some with certain staff physicians, and $17 \%$ that there are none.

Table II. Evaluation of different types of training during MIR residency

\begin{tabular}{|c|c|c|c|c|c|}
\hline & Very dissatisfied & Dissatisfied & Normal & Satisfied & Very Satisfied \\
\hline Clinical care training & $7(4 \%)$ & $18(11 \%)$ & $29(17 \%)$ & $85(51 \%)$ & $28(17 \%)$ \\
\hline Educational training & $30(18 \%)$ & $30(18 \%)$ & $47(28 \%)$ & $42(25 \%)$ & $17(10 \%)$ \\
\hline Research training & $80(48 \%)$ & $33(20 \%)$ & $22(13 \%)$ & $24(14 \%)$ & $8(5 \%)$ \\
\hline Ethical training & $27(16 \%)$ & $21(13 \%)$ & $42(25 \%)$ & $51(31 \%)$ & $23(14 \%)$ \\
\hline
\end{tabular}


On analyzing the results with respect to year of residency, we observed that residents in their $4^{\text {th }}$ or $5^{\text {th }}$ year are more dissatisfied with their research training than the rest, even though these are the ones with a higher percentage of doctoral theses, thesis topics, and scientific studies completed. Residents in their fifth year, who mainly belong in specialist surgical areas, report having more facilities for carrying out scientific activities (Table III).

If the analysis is based on specialist area, it can be seen in table IV that residents in the field of surgery carry out more theses. On the contrary, residents (MIRs) in central areas report having less facilities for carrying out scientific activities or for being able to attend courses and congresses. Finally, if we evaluate the influence that these variables have on the resident's general satisfaction with residency, it can be seen that they are significant factors of dissatisfaction (Table V).

\section{DISCUSSION}

Research and scientific training is fundamental for a good doctor, as it will allow him or her to be critical with infor- mation received, and to make his or her own advances in medicine. It has to be reminded that the fundamental aim of research in clinical medicine is to generate the knowledge that may contribute to a better understanding and utilization of the doctor's own skills in the discipline, his or her clinical care profile, as well as influence the biological, psychological and social surroundings related to the health-illness phenomenon. We cannot let those health professionals who we train be merely good technicians receptive of what others research. A critical and investigative mentality is a fundamental aspect in improving daily clinical care, as it allows the doctor to research problems found in patients in order to find solutions. What is more, such a mentality will let the doctor discern important medical advances among the avalanche of scientific information that we are faced with every day.

However, this investigative activity has always taken a backseat position in resident training, and there is little referenced information published about this topic. Accordingly, Rodríguez et al. (7), in a study carried out in residents in their fourth year of internal medicine of the digestive diseases, already reported that there are few facilities for carrying out research activities, above all for doctoral theses.

Table III. Evaluation of the scientific activity according to year of residency

\begin{tabular}{|c|c|c|c|c|c|c|}
\hline & $\begin{array}{c}R 1 \\
n=39\end{array}$ & $\begin{array}{c}R 2 \\
n=44\end{array}$ & $\begin{array}{c}R 3 \\
n=46\end{array}$ & $\begin{array}{c}R 4 \\
n=34\end{array}$ & $\begin{array}{c}R 5 \\
n=8\end{array}$ & $p$ \\
\hline $\begin{array}{l}\text { Research training evaluation } \\
\text { Very dissatisfied }(n=81) \\
\text { Dissatisfied }(n=33) \\
\text { Normal or indifferent }(n=21) \\
\text { Satisfied }(n=26) \\
\text { Very satisfied }(n=8) \\
\text { NA }(n=2)\end{array}$ & $\begin{array}{l}18(46 \%) \\
6(15 \%) \\
6(15 \%) \\
4(10 \%) \\
3(8 \%) \\
2(5 \%)\end{array}$ & $\begin{array}{l}18(41 \%) \\
8(18 \%) \\
8(18 \%) \\
8(18 \%) \\
2(5 \%) \\
0\end{array}$ & $\begin{array}{l}23(50 \%) \\
8(17 \%) \\
5(11 \%) \\
8(17 \%) \\
2(4 \%) \\
0\end{array}$ & $\begin{array}{c}+20(59 \%) \\
+8(24 \%) \\
2(6 \%) \\
3(9 \%) \\
1(3 \%) \\
0\end{array}$ & $\begin{array}{c}+2(25 \%) \\
+3(38 \%) \\
0 \\
3(38 \%) \\
0 \\
0\end{array}$ & $p=0.004$ \\
\hline $\begin{array}{l}\text { Facilities for carrying out scientific a } \\
\text { Many }(n=34) \\
\text { Only with some staff }(n=93) \\
\text { None }(n=36) \\
\text { NA }(n=8)\end{array}$ & $\begin{array}{l}\text { S } \\
10(26 \%) \\
19(49 \%) \\
5(13 \%) \\
+5(13 \%)\end{array}$ & $\begin{array}{c}5(11 \%) \\
28(64 \%) \\
9(21 \%) \\
2(5 \%)\end{array}$ & $\begin{array}{c}11(24 \%) \\
22(48 \%) \\
13(28 \%) \\
0\end{array}$ & $\begin{array}{c}4(12 \%) \\
21(62 \%) \\
9(27 \%) \\
0\end{array}$ & $\begin{array}{c}+4(50 \%) \\
3(38 \%) \\
0 \\
1(13 \%)\end{array}$ & $p=0.018$ \\
\hline $\begin{array}{l}\text { Facilities for attending courses and } \\
\text { Many }(n=77) \\
\text { Only with some staff }(n=60) \\
\text { None }(n=30) \\
\text { NA }(n=4)\end{array}$ & $\begin{array}{c}19(49 \%) \\
9(23 \%) \\
8(21 \%) \\
3(8 \%)\end{array}$ & $\begin{array}{c}17(39 \%) \\
19(43 \%) \\
8(18 \%) \\
0\end{array}$ & $\begin{array}{c}18(29 \%) \\
19(41 \%) \\
9(20 \%) \\
0\end{array}$ & $\begin{array}{c}18(53 \%) \\
10(29 \%) \\
5(15 \%) \\
1(3 \%)\end{array}$ & $\begin{array}{c}5(63 \%) \\
3(38 \%) \\
0 \\
0\end{array}$ & $p=0.292$ \\
\hline 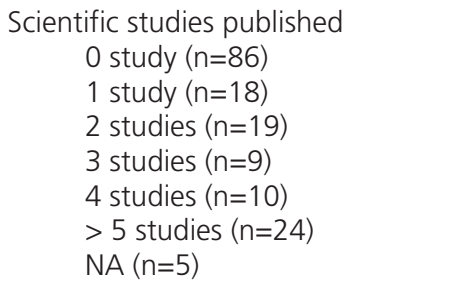 & $\begin{array}{c}+30(77 \%) \\
3(8 \%) \\
1(3 \%) \\
1(3 \%) \\
2(5 \%) \\
0 \\
2(5 \%)\end{array}$ & $\begin{array}{c}22(50 \%) \\
+9(21 \%) \\
5(11 \%) \\
0 \\
2(5 \%) \\
5(11 \%) \\
1(2 \%)\end{array}$ & $\begin{array}{c}21(46 \%) \\
3(7 \%) \\
7(15 \%) \\
3(7 \%) \\
3(7 \%) \\
+8(17 \%) \\
1(2 \%)\end{array}$ & $\begin{array}{c}12(35 \%) \\
3(9 \%) \\
4(12 \%) \\
4(12 \%) \\
1(3 \%) \\
+9(27 \%) \\
1(3 \%)\end{array}$ & $\begin{array}{c}1(13 \%) \\
0 \\
2(25 \%) \\
1(13 \%) \\
+2(25 \%) \\
+2(25 \%) \\
0\end{array}$ & $p=0.006$ \\
\hline $\begin{array}{l}\text { Thesis } \\
\qquad \begin{array}{l}\text { I have a thesis topic }(n=39) \\
\text { I have a written thesis }(n=7) \\
\text { Doctorate courses }(n=84) \\
\text { No thesis, no courses }(n=38) \\
\text { NA }(n=3)\end{array}\end{array}$ & $\begin{array}{c}-4(10 \%) \\
1(3 \%) \\
-7(18 \%) \\
+25(64 \%) \\
2(5 \%)\end{array}$ & $\begin{array}{c}9(21 \%) \\
2(5 \%) \\
26(59 \%) \\
7(16 \%) \\
0\end{array}$ & $\begin{array}{c}15(33 \%) \\
3(7 \%) \\
23(50 \%) \\
4(9 \%) \\
1(2 \%)\end{array}$ & $\begin{array}{c}7(21 \%) \\
0 \\
+25(74 \%) \\
2(6 \%) \\
0\end{array}$ & $\begin{array}{c}4(50 \%) \\
1(13 \%) \\
3(38 \%) \\
0 \\
0\end{array}$ & $p<0.0001$ \\
\hline
\end{tabular}


Table IV. Evaluation of the scientific activity according to the speciality

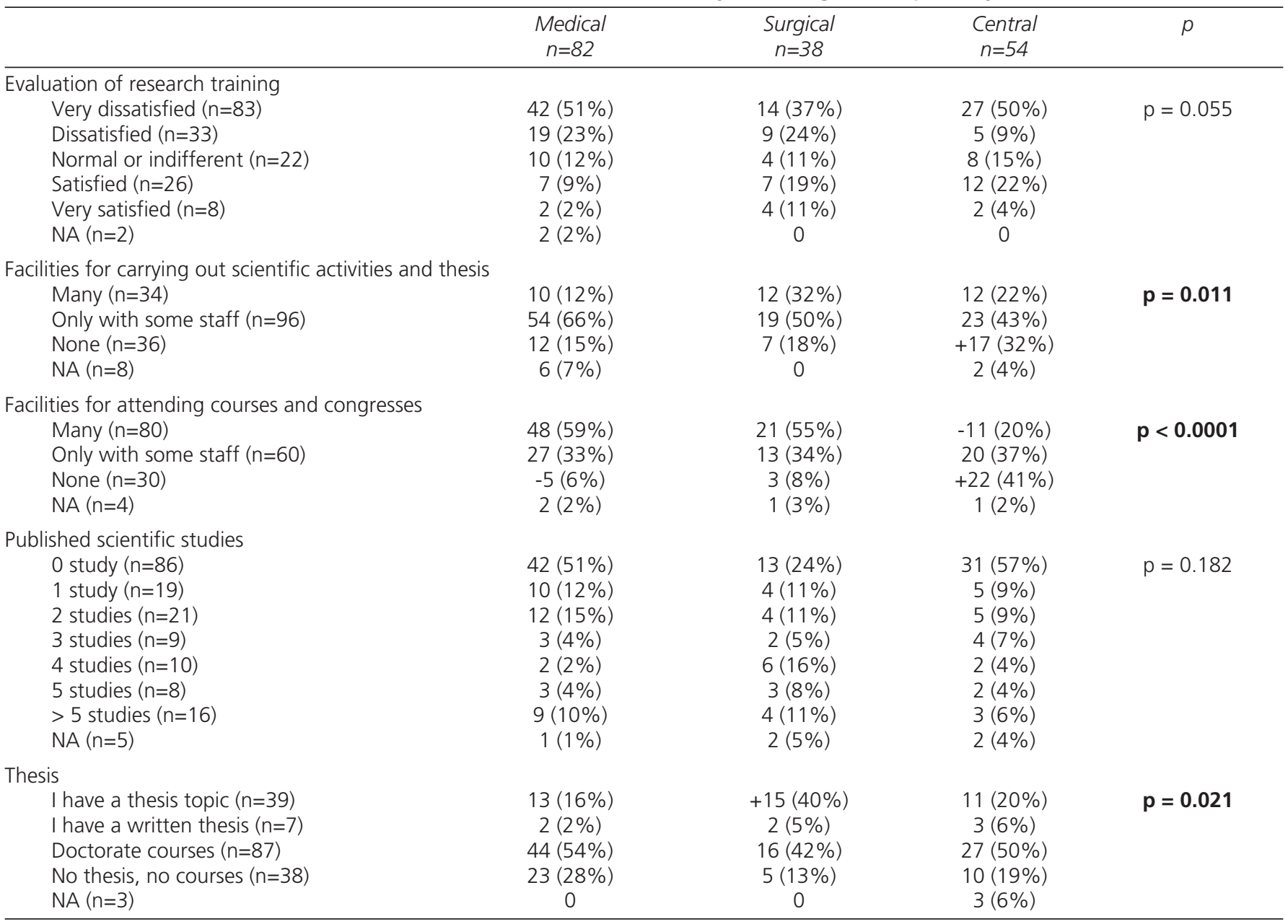

These data correlate with our own, which show that $68 \%$ of residents are dissatisfied with their research training, and only $28 \%$ have a thesis topic or have undertaken their thesis. It is important to comment that what is fundamental is to encourage research activity, and that the necessary bases should be acquired for carrying out such research as staff physicians. In fact, those who acquire such abilities usually complete their doctoral thesis, but this may well be after finishing their residency (11). It should be taken into account that the profile of a resident (MIR) is that of a young graduate (aged $27 \pm 7$ years) who has not had to sit a MIR exam on too many occasions, and, as this training is his/her first activity as a doctor, it is a really crucial stage for the rest of her or his professional life.

Moreover, currently, above all in specialist areas with a high level of unemployment, research has become a major source of employment (11). Thus, in certain specialities, after a training period, more than half of residents have continued their connection with their departments as research assistants with grants, thus carrying out research tasks (11). However, it must be said that this is not the best option, as it creates a situation of underemployment that forces doctors to have more than one job, with the clearest example being contracts for doing day and night duty in order to earn an acceptable level of income. Additionally, it must be considered that research and scientific activity is an expectation that most residents have when they arrive at a hospital. Therefore, when such an expectation is not fulfilled it becomes a factor of dissatisfaction (7). In our study we have seen that the different variables related to research are factors for dissatisfaction when they are not fulfilled, as seen in table V.

In this sense, the figure of the tutor is without doubt a crucial element. This person is responsible for carrying out essential tasks for resident training quality, such as training plans for each resident, direct and continued supervision of residents in their work, a continued evaluation of their learning, and making the most of training received. Therefore, this figure is fundamental for completing resident research training.

Our study highlights how dissatisfaction towards research training increases with the year of residency, and 
Table V. Evaluation of residents' satisfaction according to facilities for carrying out scientific activities

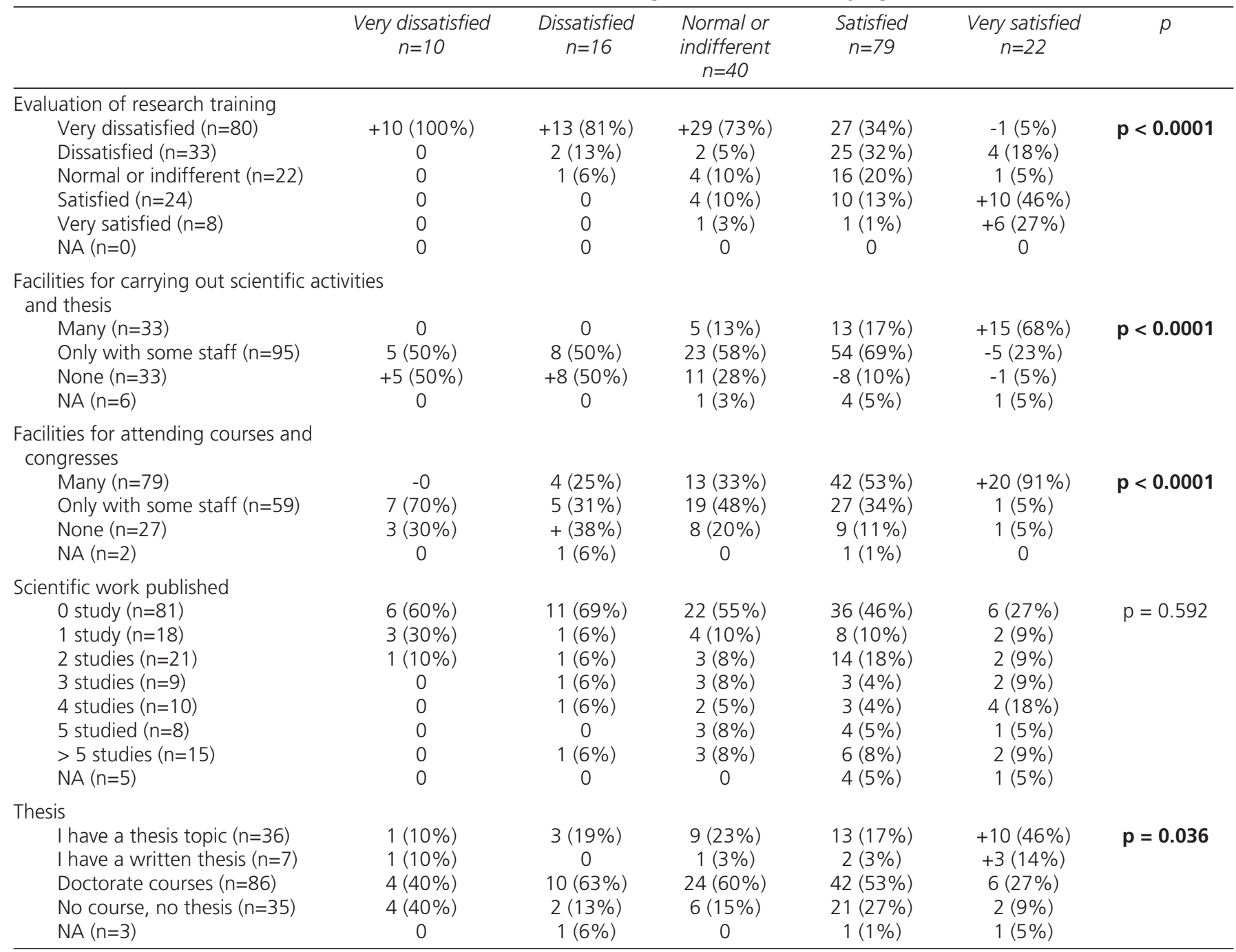

how research expectations are not fulfilled. This is only logical, as the "younger" first-year resident always thinks that there is time to learn, but as the end of residency approaches he or she realizes what the limitations of their training have been.

Although this questionnaire is not totally applicable to all hospitals, since each hospital has its own peculiarities, in general terms, problems are similar -there are sufficient data to confirm dissatisfaction of internal residents with their scientific training, and the facilities they have for carrying it out are relatively scarce, which is why options should be sought to resolve this negative effect on training.

\section{REFERENCES}

1. Carrasco AL. Estructura docente y calidad en la formación médica especializada. Med Clin 1994; 103: 577-8.

2. Pujol R, Busquet J, Feliu E, Castellsague J, Gómez JM, Martínez JM, et al. Evaluación de la competencia clínica de una población de médicos especialistas formados por el sistema MIR. Med Clin 1995; 105: 491-5.

3. Miño G. Aparato Digestivo. Enseñanza de la especialidad. Consideraciones generales sobre diferentes modelos de formación. Rev And Pat Digest 1998; 21: 249-51.

4. Pujol R. Médicos residentes (MIR) insatisfechos. Med Clin 1997; 109: 623-4

5. Fernández J, Julián JF, Hidalgo F, García F, Moreno P, Vega JL, et al. Encuesta a residentes MIR sobre su satisfacción tras obtener una plaza hospitalaria. Med Clin 1997; 109: 615-8.

6. Martín Zurro A. Sobre la especialización de los profesionales médicos. Med Clin 1996; 106: 254-6.

7. Rodríguez FJ, Puente J, Chicano M, Monrobel A, López D, Bernal E, et al. Formación MIR en aparato digestivo. El punto de vista de los residentes. Gastroenterol Hepatol 2000; 23: 367-73.

8. Cohen JJ. Heeding the plea to deal with resident stress. Ann Intern Med 2002; 136: 394-5.

9. Belloch SL, Renovell V, Calabuig JR, Gómez L. Síndrome de agotamiento profesional en médicos residentes de especialidades médicas hospitalarias. An Med Interna 2000; 17: 118-22.

10. Piqué JM, Arroyo V, Planas R, Pérez-Mateo M, Prieto J. La formación de especialistas en aparato digestivo. ¿Llegó el momento de la revisión? Gastroenterol Hepatol 2003; 26: 427-36.

11. Rosell A, Miravitlles M, Roger N, Jolis R, Llunell A, Morell F. Los residentes de neumología formados en Cataluña (1989-1993). Med Clin 1996; 106: 653-5. 


\title{
Formación investigadora durante la residencia MIR. Encuesta de satisfacción
}

\author{
A. Ríos Zambudio, F. Sánchez Gascón, L. González Moro y M. Guerrero Fernández \\ Departamento de Cirugía General y del Aparato Digestivo. Comisión de Docencia. Hospital Universitario Virgen de la \\ Arrixaca. El Palmar. Murcia
}

\section{RESUMEN}

Introducción: durante la residencia MIR se van a adquirir los conocimientos, habilidades y hábitos que van a marcar la actividad profesional en el futuro. Por ello, es muy probable que los residentes que no adquieran el hábito y los conocimientos necesarios para realizar actividades investigadoras no realicen dichas actividades en el futuro. El objetivo es analizar la satisfacción de los MIR con su formación científica e investigadora, y determinar los déficits al respecto en su formación.

Material y método: se aplicó un cuestionario destinado a constatar la satisfacción de los residentes respecto a su formación científica e investigadora durante el transcurso de su residencia. Los cuestionarios se distribuyeron nominalmente por correo interno a todos los MIR registrados en un hospital de tercer nivel acreditado para docencia, siendo el grado de cumplimentación del $78 \%(n=178)$.

Resultados: en cuanto a la valoración de la formación científica, el 68\% están insatisfechos o muy insatisfechos. Respecto a la realización de trabajos científicos, el 49\% de los residentes no han escrito ninguno, aunque aumenta el número de trabajos realizados conforme avanza el tiempo de residencia. Por otro lado, el 22\% refiere no tener iniciada la tesis doctoral, el 50\% haber realizado los cursos de doctorado, el $24 \%$ tiene tema de tesis, y sólo el $4 \%$ la ha escrito. Los cursos, el tema de tesis y el haberla escrito van aumentando con el año de residencia, y se observa una mayor actividad en este sentido en los servicios quirúrgicos. Si analizamos las facilidades que tienen los residentes para realizar actividades científicas, el 55\% refieren que sólo con determinados adjuntos, y el 21\% que ninguna. La insatisfacción con la formación investigadora aumenta conforme aumenta el año de residencia. En cuando al área troncal de la especialidad, se observa que realizan más tesis los residentes de las áreas quirúrgicas, y que los de áreas centrales refieren menos facilidades. Por último, si se valora la influencia que estas variables pueden tener en la satisfacción general del residente con su residencia, se observa que son factores significativos de insatisfacción.

Conclusiones: la mayoría de los residentes están insatisfechos con su formación científica y tienen relativamente pocas facilidades para poder desarrollarla, lo cual se plasma en un escaso número de trabajos científicos y tesis doctorales.

Palabras clave: Médicos internos residentes. Formación científica. Satisfacción. Tesis. Publicaciones.

\section{INTRODUCCIÓN}

Está ampliamente reconocido que la formación obtenida por el programa de formación médica especializada mediante el sistema de residencia (sistema MIR), tiene una gran cualificación y ha mejorado la calidad asistencial de los hospitales (1-3), aunque hay aspectos que son susceptibles de mejora (3-10). Durante esta época postgraduada de especialización de un médico es cuando mejoran rápidamente sus conocimientos y, en consecuencia, debe aprovecharse al máximo para su propio beneficio y para el del sistema sanitario en general (4).

Hay que tener en cuenta que durante este periodo formativo es cuando se van a adquirir los conocimientos, habilidades y hábitos, en todas sus vertientes (clínica, docente, investigadora y ética) que van a marcar su actividad profesional en el futuro. En este sentido, los residentes que no adquieran el hábito y los conocimientos necesarios para realizar actividades investigadoras, es muy probable que no realicen dichas actividades en el futuro. Por ello, es fundamental que los responsables de la docencia MIR fomentemos dichas actividades, para formar buenos residentes con buenas bases clínicas, científicas e investigadoras, docentes y éticas. Además, es importante saber cuál es la situación actual de los residentes en cuanto a su formación investigadora, y cómo es valorada por ellos.

El objetivo de este trabajo es analizar la satisfacción de los médicos internos residentes de nuestro hospital con su formación científica e investigadora, y determinar los déficits al respecto en su formación.

\section{MATERIAL Y MÉTODOS}

El estudio se llevó a cabo en un hospital de tercer nivel acreditado para la docencia pre y postgraduada. Se elaboró un cuestionario (15 preguntas de elección múltiple) destinado a constatar la satisfacción de los MIR respecto a su formación científica e investigadora durante el transcurso de su residencia. En las preguntas de valoración se ha utilizado una escala de variables continuas discretas (de 0 a 10) que posteriormente se ha diferenciado en cinco categorías: 0-2 muy insatisfecho; 3-4 insatisfecho; 5-6 normal o indiferente; 7-8 satisfecho, y 9-10 muy satisfecho.

Los cuestionarios se distribuyeron nominalmente por correo interno, entre los meses de febrero y marzo del 2002, a todos los MIR registrados en el hospital en dicha fecha. La encuesta fue anónima y autodirigida, y se entregó en sobre cerrado en la secretaría de docencia de nuestro hospital. De 
los 237 residentes del hospital se han excluido los que estaban en comisión de servicio en el momento de realizar la encuesta $(n=10)$, resultando 227 a los que se les distribuyó la encuesta, contestando a la misma 178 (78\%). Se han excluido 3 por entregarlas en blanco, resultando 175 encuestas válidas $(77 \%)$. Existía un ligero predominio de las mujeres en la muestra $(\mathrm{n}=98 ; 56 \%)$ y la edad media se situó en los $27 \pm$ 7 años (24-45 años). En cuanto al grupo troncal de especialidad el $47 \%(n=82)$ eran de especialidades médicas, el $22 \%$ $(n=38)$ de quirúrgicas, y el $31 \%(n=54)$ de servicios centrales; en el caso restante $(0,6 \%)$ no constaba la especialidad. En cuanto al año de residencia el $22 \%(n=39)$ eran residentes de primer año, el 25\% (n=44) de segundo, el 26\% ( $n=46)$ de tercero, el $20 \%(n=34)$ de cuarto y el $5 \%(n=8)$ de quinto año; en los 4 casos restantes no constaba el año de residencia.

Las variables analizadas fueron los datos de filiación (edad, sexo, año de residencia, y grupo troncal de la especialidad), la existencia de sesiones en su servicio (de urgencias, clínicas, bibliográficas y de morbi-mortalidad), la valoración de los diferentes tipos de formación que recibe el MIR (asistencial, docente, investigadora y ética), las facilidades para realizar actividades científicas, las facilidades para asistir a cursos y congresos, los trabajos científicos publicados, y la situación actual ante la realización de su tesis (tesis ya escrita, tema de tesis, cursos del doctorado, o ni cursos ni tesis).

Se realizó estadística descriptiva de cada una de las variables, y para detectar los factores que influyen en la insatisfacción con la residencia se realizó una comparación entre el grado de satisfacción global con la residencia y el resto de variables a través del test de $\chi^{2}$ cumplimentado con el análisis de residuos y el test exacto de Fisher si era necesario. Se consideró estadísticamente significativo un valor de $\mathrm{p}$ inferior a 0,05 .

\section{RESULTADOS}

Respecto a la valoración de las sesiones realizadas en sus servicios, en sus diferentes variedades (urgencias, clínicas, bibliográficas y de morbi-mortalidad), las sesiones clínicas suelen ser habituales en la mayoría de servicios (69\%). Sin embargo, como puede verse en la tabla I, un alto porcentaje de residentes no tienen acceso, o este es ocasional, en su servicio, a sesiones de diversos tipos. Así, el $85 \%$ refieren no tener sesiones de morbi-mortalidad o sólo ocasionalmente; lo mismo ocurre respecto a las sesiones bibliográficas con el $59 \%$ de los casos.
Tabla I. Sesiones de los diferentes tipos a los que tienen acceso en su servicio los distintos residentes

\begin{tabular}{lcccc}
\hline & No & Ocasionalmente & Habitualmente & NSINC \\
\hline Sesiones de urgencias & $76(46 \%)$ & $28(17 \%)$ & $48(29 \%)$ & $15(9 \%)$ \\
Sesiones clínicas & $15(9 \%)$ & $36(22 \%)$ & $115(69 \%)$ & $1(1 \%)$ \\
Sesiones bibliográficas & $49(29 \%)$ & $50(30 \%)$ & $66(40 \%)$ & $2(1 \%)$ \\
Sesiones de morbi-mortalidad & $115(69 \%)$ & $27(16 \%)$ & $11(7 \%)$ & $14(8 \%)$ \\
\hline
\end{tabular}

En cuanto a la valoración de la formación, como se ve en la tabla II, esta varía según la vertiente de la misma que analicemos. Así, respecto a la formación asistencial, sólo el $15 \%$ están insatisfechos o muy insatisfechos, mientras que en la valoración de la formación docente, el índice aumenta al $36 \%$, y en lo referente a la formación investigadora hasta el $68 \%$.

Respecto a la realización de trabajos científicos, el $49 \%$ de los residentes no han escrito ninguno, y se observa que dicho número de trabajos científicos publicados aumenta conforme aumenta el tiempo de residencia, sin observarse diferencias por grupo troncal de especialidad. Por otro lado, el $22 \%$ refiere no tener nada de la tesis doctoral, el $50 \%$ refiere haber realizado los cursos de doctorado, el $24 \%$ tiene tema de tesis, y sólo el $4 \%$ la ha escrito. Los cursos, el tema de tesis y el haberla escrito van aumentando con el año de residencia, y se observa una mayor actividad en este sentido en los servicios quirúrgicos. Si analizamos las facilidades que tienen los residentes para realizar actividades científicas, el 19\% refieren que muchas, el $55 \%$ que sólo con algunos adjuntos, y el $21 \%$ que ninguna. En cuanto a las facilidades para asistir a cursos y congresos, el $46 \%$ refieren que tienen muchas, el $34 \%$ sólo con determinados adjuntos, y el $17 \%$ ninguna.

$\mathrm{Al}$ analizar los resultados por el año de residencia, observamos que los residentes de $4^{\circ}$ y $5^{\circ}$ año están más insatisfechos con su formación investigadora que el resto. Aunque son estos los que tienen un mayor porcentaje de tesis doctorales y temas de tesis, y los que han escrito más trabajos científicos. Los residentes de quinto año, que pertenecen principalmente a especialidades quirúrgicas, refieren una mayor facilidad para realizar actividades científicas (Tabla III).

Si el análisis se realiza en función del área troncal de la especialidad, se observa en la tabla IV que realizan más tesis los residentes de las áreas quirúrgicas, y que los MIR de áreas centrales refieren menos facilidades para realizar actividades científicas, y poder asistir a cursos y congresos.

Por último, si se valora la influencia que estas variables pueden tener en la satisfacción general del residente con su

Tabla II. Valoración por los residentes de los distintos tipos de formación durante la residencia MIR

\begin{tabular}{|c|c|c|c|c|c|}
\hline & Muy insatisfecho & Insatisfecho & Normal & Satisfecho & Muy satisfecho \\
\hline Formación asistencial & $7(4 \%)$ & $18(11 \%)$ & $29(17 \%)$ & $85(51 \%)$ & $28(17 \%)$ \\
\hline Formación docente & $30(18 \%)$ & $30(18 \%)$ & $47(28 \%)$ & $42(25 \%)$ & $17(10 \%)$ \\
\hline Formación investigadora & $80(48 \%)$ & $33(20 \%)$ & $22(13 \%)$ & $24(14 \%)$ & $8(5 \%)$ \\
\hline Formación ética & $27(16 \%)$ & $21(13 \%)$ & $42(25 \%)$ & $51(31 \%)$ & $23(14 \%)$ \\
\hline
\end{tabular}


Tabla III. Valoración por los residentes de la actividad científica en función del año de residencia

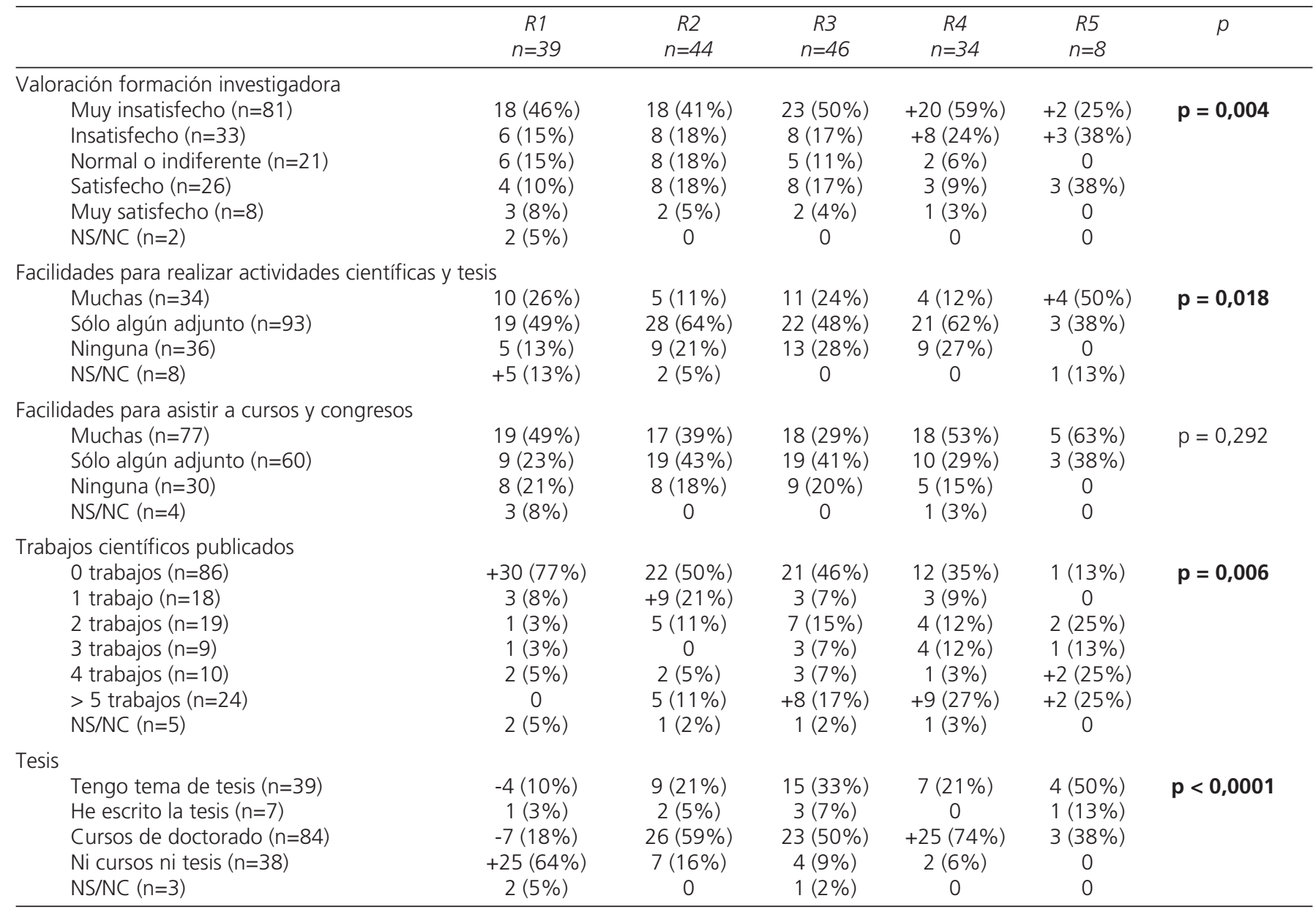

residencia, se observa que son factores significativos de insatisfacción (Tabla V).

\section{DISCUSIÓN}

La formación investigadora y científica es fundamental en un buen médico, pues le va a permitir ser crítico con la información que recibe y realizar sus propios avances en la medicina. Hay que recordar que el propósito fundamental de la investigación en la medicina clínica es generar conocimientos que permitan contribuir a la mejor comprensión y utilización de los recursos propios de la disciplina, su perfil asistencial, así como influir en el entorno biológico, psicológico y social en relación con el fenómeno salud-enfermedad. No podemos permitir que los profesionales sanitarios que formamos sean sólo unos buenos técnicos receptores de lo que otros profesionales investigan. La mentalidad crítica e investigadora es un aspecto fundamental en la mejora de la asistencia clínica diaria, pues permite al médico investigar los problemas que encuentra en la cabecera del enfermo para dar soluciones y no tener que esperar de forma pasiva a que le llegue la solución. Además dicha mentalidad le permitirá discernir los avances médicos importantes entre la avalancha de información científica a la que estamos sometidos hoy día.

Sin embargo, esta actividad investigadora ha estado siempre en un segundo plano en la formación de los residentes, y pocos son los datos referenciados en la literatura sobre este tema. En este sentido, Rodríguez y cols. (7), en un estudio realizado en residentes de $4^{\circ}$ año de medicina interna de aparato digestivo, ya refiere que existen pocas facilidades para realizar actividades de investigación, sobre todo la tesis doctoral. Estos datos se correlacionan con los nuestros que muestran que el $68 \%$ de los residentes están insatisfechos con su formación investigadora, y sólo un $28 \%$ tienen tema de tesis o han realizado la misma. Es importante comentar que lo fundamental es fomentar la actividad investigadora y que adquieran las bases suficientes para poder realizar dicha investigación como adjuntos. Pues aquellos que adquieren dichas habilidades suelen realizar su tesis doctoral aunque sea una vez acabada la residencia (11). Hay que tener en cuenta que el perfil del MIR es el de un licenciado joven (edad $27 \pm 7$ años) que no ha tenido que presentarse en de- 
Tabla IV. Valoración por los residentes de la actividad científica en función del área troncal de su especialidad

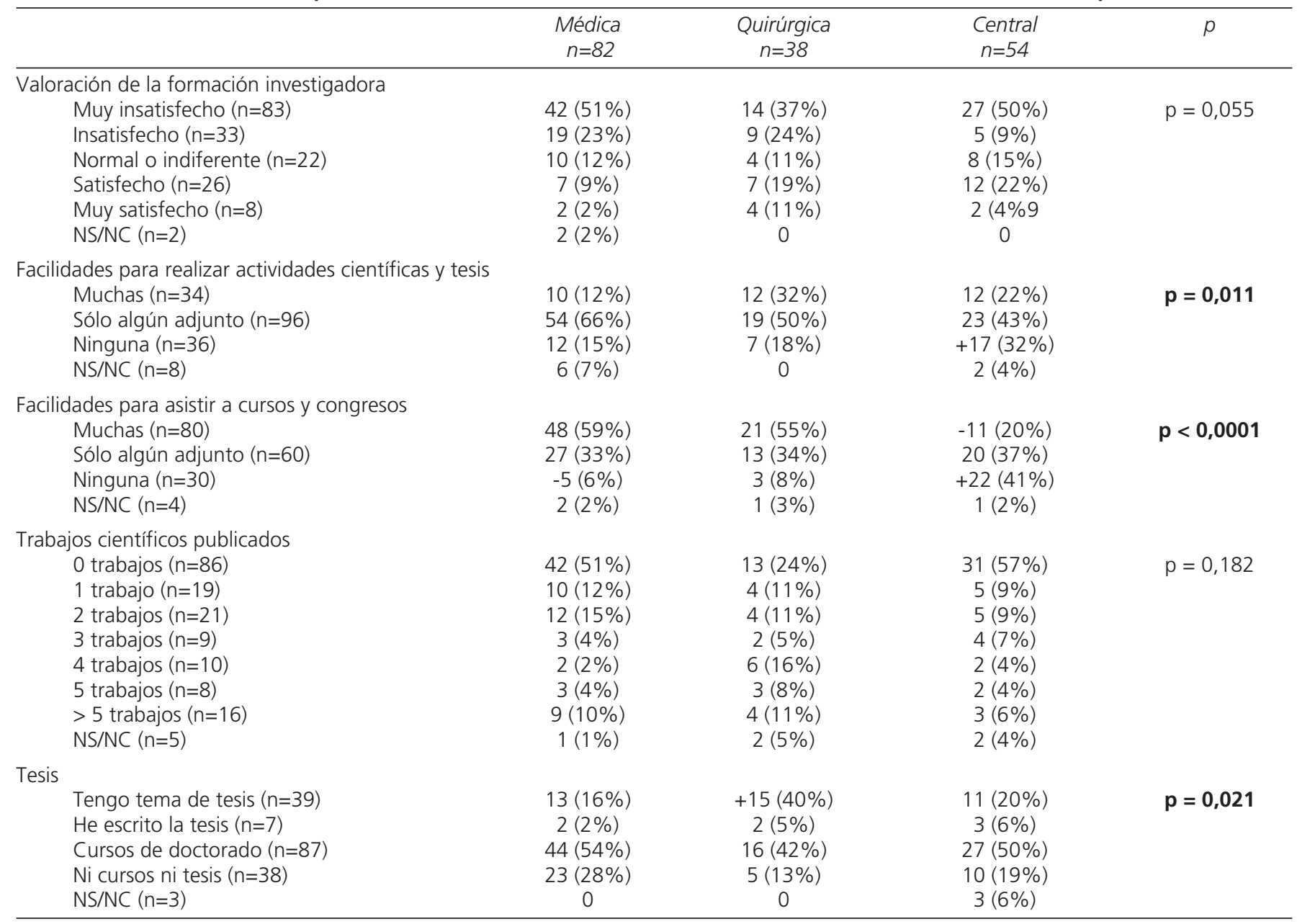

masiadas ocasiones al examen MIR, por lo que al ser esta formación su primera actividad como médico, se trata de una época realmente crucial para el resto de su vida profesional.

Además, en la actualidad, sobre todo en las especialidades con alto cupo de desempleo, la investigación se ha convertido en una fuente de trabajo (11). Así, en determinadas especialidades, después de su periodo de formación más de la mitad de los residentes han seguido vinculados a sus servicios en calidad de becarios, realizando tareas de investigación (11). Si bien hay que decir que este no es el planteamiento ideal pues se crea una situación de subempleo, que obliga a recurrir al pluriempleo, siendo su máxima expresión la realización de guardias, para conseguir alcanzar un nivel de ingresos aceptable. Además, hay que tener en cuenta que la actividad investigadora-científica, es una expectativa que tienen la mayoría de los residentes cuando llegan al hospital. Por ello, cuando no se cumple dicha expectativa, se convierte en un factor de insatisfacción (7). En nuestro estudio se observa cómo las distintas variables asociadas con la investigación que analizamos son un factor de insatisfacción, en función de que se cumplan o no.

En este sentido, la figura del tutor constituye, sin duda, el elemento nuclear. Sobre él recae la responsabilidad de llevar a cabo tareas esenciales para la calidad formativa del residente como es el plan individual de formación de cada residente, la supervisión directa y continua de los residentes a su cargo y la evaluación continuada del aprendizaje y aprovechamiento de la formación recibida. Por ello esta figura es fundamental para completar la formación investigadora del residente.

En nuestro estudio destaca cómo la insatisfacción respecto a la formación investigadora va aumentando conforme aumentan los años de residencia y no se cumplen sus expectativas investigadoras. Esto es lógico, pues de residente "pequeño" de primer año siempre se piensa que queda tiempo para aprender, pero conforme se acerca el final de la residencia uno se da cuenta de cuáles han sido las limitaciones de su formación. 
Tabla V. Valoración de la satisfacción de los residentes en función de sus facilidades para realizar actividades científicas

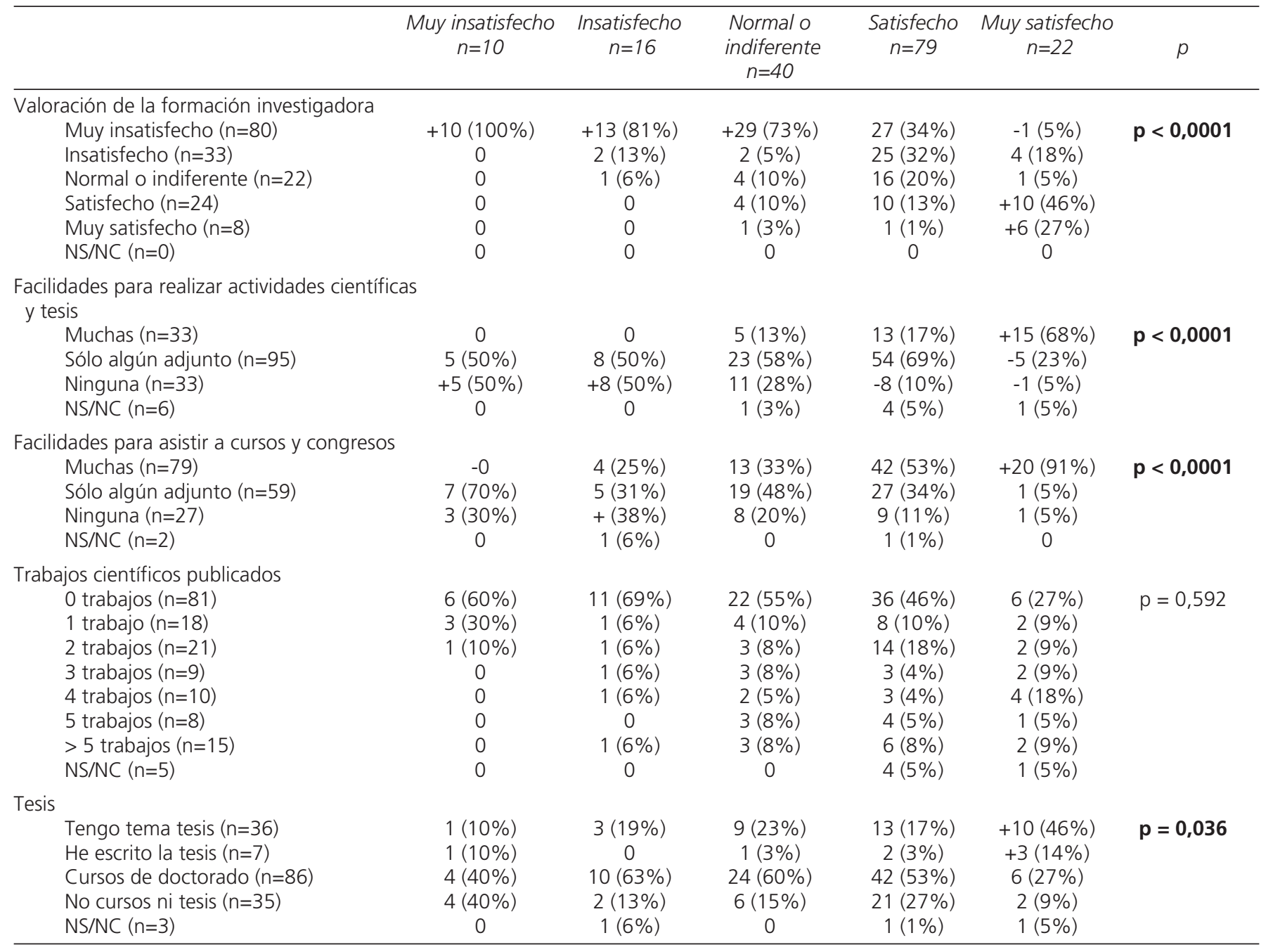

Aunque, posiblemente esta encuesta no sea totalmente extrapolable a todos los hospitales dado que cada uno presenta sus peculiaridades, en líneas generales los problemas son similares, y hay datos suficientes para confirmar que el grado de satisfacción de los médicos internos residentes con su formación científica y la facilidades que tienen para poder llevarlas a cabo son relativamente bajas, por lo que se deben buscar opciones para resolver este negativo impacto en la formación. 